\title{
Cloning and Amplification of the Adenylate Cyclase Gene
}

\author{
Kenji Kano, ${ }^{*}$ Kousaku Murata, Akira Kimura \\ and Hiroji AIBA** \\ Research Institute for Food Science, Kyoto University, \\ Uji, Kyoto 611, Japan \\ *Seitetsu Kagaku Kogyo Co., Ltd., Harima, \\ Kako-gun, Hyogo 675-01, Japan \\ ** Radioisotope Laboratory, Faculty of Medicine, \\ Kyoto University, Kyoto 606, Japan
}

Received November 29, 1982

\begin{abstract}
The gene (cya) responsible for adenylate cyclase activity of $E$. coli was cloned onto pBR322 and the hybrid plasmid carrying the cya gene was designated as PCAK-11. The hybrid plasmid was 6.0 Md in size and contained a 3.3 Md HindIII fragment derived from E. coli strain CA7902R chromosomal DNA. In various $E$. coli hosts, the hybrid plasmid coded for high adenylate cyclase activity. E. coli cells dosed with pCAK-11 accumulated a large amount of cAMP in both cells and broth. Especially marked accumulation of cAMP was found in a strain deficient in cAMP-receptor protein (CRP).
\end{abstract}

In both eukaryotes and prokaryotes, the intracellular response to extracellular stimuli is mediated by adenosine $3^{\prime}, 5^{\prime}$-cyclic monophosphate (cAMP). ${ }^{1}$ 3) Although cAMP has various actions in prokaryotes, the mechanisms of these actions are little known except for its action at the transcriptional level in E. coli. ${ }^{4}$ In $E$. coli, approximately 30 operons are supposedly controlled by cAMP. ${ }^{2)}$ For expression of these genes, the participation of cAMP and its receptor protein (CRP) are required as a positive $^{4)}$ or negative ${ }^{5)}$ effector.

The intracellular level of cAMP, therefore, is one of the important factors for the elucidation of the mechanism of gene expression. In $E$. coli cells, the intracellular concentration of cAMP is considered to be controlled in various ways. They are (i) synthesis by the adenylate cyclase reaction, (ii) excretion of cAMP into the growth medium and (iii) degradation catalyzed by cAMP-phosphodiesterase (CPD). Recently, effects of CRP on both regulation of the intracellular level of cAMP and adenylate cyclase activity were also reported. $^{6,7)}$

For elucidation of the functions of cAMP and for construction of a highly potent producer of cAMP, we first cloned the gene responsible for the adenylate cyclase activity onto pBR322 and introduced the hybrid plasmid, designated as pCAK-11, into various $E$. coli strains having deficiencies in genes responsible for the metabolism of cAMP. This article deals with the relationship between adenylate cyclase activity and the intra- and/or extra-cellular level of cAMP.

\section{MATERIALS AND METHODS}

Bacterial strains of $E$. coli $K-12$. Strains used and their genetic properties were listed in Table I. Strain CA7902 (Hfr thi relA cya), a mutant strain deficient in adenylate cyclase $\left(\mathrm{cya}^{-}\right)$activity, was a gift from M. Yamazaki. CA7902R was a revertant derived from CA7902 by $N$ methyl- $N^{\prime}$-nitro- $N$-nitrosoguanidine treatment according to the method of Adelberg et al. ${ }^{8)}$ Strain pp47, a mutant strain deficient in cAMP-receptor protein (CRP), was derived from strain pp6.

Preparation of DNAs. Chromosomal DNA was isolated from CA7902R $\left(\right.$ cya $\left.^{+}\right)$by the method of Miura. ${ }^{9}$ Plasmid DNA was purified from the cleared lysates of CA7902 according to the procedure Clewell et al. ${ }^{10)}$

Construction of hybrid plasmids. Hybrid plasmids were 
TABle I. Strains USED

\begin{tabular}{lll}
\hline \multicolumn{1}{c}{ Strain } & Relevant genotype & \multicolumn{1}{c}{ Source } \\
\hline CA7902 & $c y a^{-}, c r p^{+}, c p d^{+a}$ & J. Beckwith \\
CA7902R & $c y a^{+}, c r p^{+}, c p d^{+}$ & This work \\
pp6 & $c y a^{+}, c r p^{+}, c p d^{+}$ & I. Pastan \\
pp47 & $c y a^{+}, c r p^{-}, c p d^{+}$ & I. Pastan \\
Crooke's & $c y a^{+}, c r p^{+}, c p d^{-}$ & (ATCC8739) \\
\hline
\end{tabular}

a Gene for cAMP phosphodiesterase.

constructed using plasmid pBR322 as a cloning vector. pBR322 was cleaved with HindIII and treated with bacterial alkaline phosphatase as described by Ullrich et al. ${ }^{11}$ $3.0 \mu \mathrm{g}$ of chromosomal DNA from CA7902R was digested with restriction endonuclease $H$ indIII for 15,30 and 60 min at $37^{\circ} \mathrm{C}$ and then ligated with $1.0 \mu \mathrm{g}$ of pBR322 by $\mathrm{T}_{4}$ DNA ligase according to the method of Tanaka and Weisblum. ${ }^{12)}$

Transformation. The whole ligation mixture thus prepared was used for the transformation of CA7902 (cya $\left.{ }^{-}\right)$ by the method of Kushner. ${ }^{13)}$ The method for the selection of transformants is described in RESULTS.

Restriction mapping of hybrid plasmid pCAK-11. Restriction mapping of hybrid plasmid pCAK-11 was carried out with various restriction endonucleases. The reaction conditions were the same as those described by Murata et al. ${ }^{14)}$ Agarose gel (slab type, $1.0 \%$ ) electrophoresis was carried out using the same buffer as described by Helling et al. ${ }^{15)}$

Assay for adenylate cyclase activity. Adenylate cyclase activity was determined by the method of Tao et al. ${ }^{16)} \mathrm{E}$. coli cells were grown to the late log phase on DavisMingioli minimal medium ${ }^{17}$ ) (glucose $1.0 \%$ ) supplemented with $0.25 \%$ yeast extract and $0.4 \%$ polypeptone. The cells were harvested by centrifugation at $8,000 \mathrm{rpm}$ for $10 \mathrm{~min}$ and washed once with $10 \mathrm{~mm}$ Tris- $\mathrm{HCl}$ buffer $(\mathrm{pH} 8.0)$ containing $10 \mathrm{~mm} \mathrm{MgSO}_{4}$. The washed cells were resuspended in $10 \mathrm{ml} / \mathrm{g}$ wet wt. cells of $20 \mathrm{~mm}$ Tris- $\mathrm{HCl}$ buffer ( $\mathrm{pH} 8.0$ ) containing $10 \mathrm{~mm} \mathrm{MgSO}_{4}, 0.25 \mathrm{~mm}$ ethylenediaminetetraacetate and $1.0 \mathrm{~mm}$ dithiothreitol. The cell suspensions were sonicated at $90 \mathrm{kHz}$ for $30 \mathrm{sec}$ at $0^{\circ} \mathrm{C}$ and then used as the enzyme sources. The adenylate cyclase reaction was carried out in a $1.0 \mathrm{ml}$ mixture containing $50 \mathrm{~mm}$ Tris- $\mathrm{HCl}$ buffer ( $\mathrm{pH} 9.0$ ), $20 \mathrm{~mm} \mathrm{MgSO}_{4}, 4.0 \mathrm{~mm}$ adenosine $5^{\prime}$-triphosphate (ATP) and cell extracts at $34^{\circ} \mathrm{C}$ for $30 \mathrm{~min}$.

Measurement of $c A M P$. The cAMP formed in the reaction mixture was assayed by a radioimmunoassay using a cAMP assay kit obtained from Yamasa Shoyu Co., Ltd., Chiba, Japan. The cAMP content of cells was determined as follows. The cells $(0.1 \mathrm{~g}$ wet wt.) in the late log phase on Davis-Mingioli minimal medium supplemented with $0.02 \%$ yeast extract were extracted for cAMP with $20 \mathrm{ml}$ of $6.0 \%$ perchloric acid for $10 \mathrm{~min}$ at $4^{\circ} \mathrm{C}$. After neutralization with about $0.2 \mathrm{ml}$ of $60 \% \mathrm{KOH}$, the mixture was made up $5.0 \mathrm{ml}$ and centrifuged at $3,000 \mathrm{rpm}$ for 10 min. The resultant supernatants were used for the determination of cAMP. The cAMP in the broth was determined using the culture filtrates. Protein was determined by the method of Lowry et al. ${ }^{18)}$

Chemicals. The chemicals used were all analytical grade reagents. Restriction endonucleases and $\mathrm{T}_{4}$ DNA ligase were purchased from Takara Shuzo Co., Ltd., Kyoto, Japan.

\section{RESULTS}

Transformation and selection of hybrid plasmids containing the gene for adenylate cyclase

The criterion for the selection of hybrid plasmids carrying the cya gene was as follows. In $E$. coli, cAMP is indispensably required for the expression of the lactose operon. ${ }^{4)}$ Cells lacking in cAMP represent a $\mathrm{Lac}^{-}$phenotype and give small white colonies on MacConkeylactose agar plates. ${ }^{19)}$ On the other hand, cells transformed with a hybrid plasmid carrying the cya gene show a $\mathrm{Lac}^{+}$phenotype and show red colour colonies on MacConkey-lactose agar plates. Therefore, the transformants habouring the hybrid plasmid with the cya gene can be selected as the red colonies on MacConkey-lactose plates.

E. coli mutant CA7902 with a point mutation in the cya region was incubated with the whole ligation mixture consisting of pBR322 and HindIII restriction fragments of chromosomal DNA from CA7902R and spread on MacConkey-lactose agar plates supplemented with $20 \mu \mathrm{g} / \mathrm{ml}$ ampicillin. Transformants were selected as red colour-producing and ampicillin-resistant colonies. The frequency of the appearance of such colonies varied depending on the digestion time of chromosomal DNA. The numbers of transformants obtained for 15,30 and $60 \mathrm{~min}$ digests of chromosomal DNA were 1, 18 and 5 per two thousand ampicillin-resistant colonies, respectively. 
TABle II. Characterization of Transformants Obtained

\begin{tabular}{|c|c|c|c|c|}
\hline \multirow{2}{*}{ Strain } & \multirow{2}{*}{$\begin{array}{c}\text { Plasmid } \\
\text { dependent } \\
\mathrm{Lac}^{+} \text {phenotype }^{a}\end{array}$} & \multicolumn{2}{|c|}{ Generation time on ${ }^{b}$} & \multirow{2}{*}{$\begin{array}{c}\text { Adenylate } \\
\text { cyclase } \\
\text { activity }^{c}\end{array}$} \\
\hline & & Lactose & Maltose & \\
\hline \multirow{3}{*}{$\begin{array}{l}\text { CA7902 } \\
\text { CA7902R } \\
\text { CA7902/pBR322 }\end{array}$} & - & - & - & 1 \\
\hline & - & 1.0 & 1.0 & 26 \\
\hline & 0 & - & - & 3 \\
\hline \multirow[t]{9}{*}{ Transformant } & 0.87 & 4.5 & - & 0.01 \\
\hline & 0.01 & 4.0 & - & 3 \\
\hline & 0.88 & 4.5 & 3.0 & 7 \\
\hline & 1.00 & 6.0 & 4.0 & 2 \\
\hline & 1.00 & 1.0 & - & 3 \\
\hline & 1.00 & 1.0 & 1.0 & 28 \\
\hline & 1.00 & 1.0 & 1.0 & 24 \\
\hline & 1.00 & 1.0 & 1.0 & 22 \\
\hline & 1.00 & 1.0 & 1.0 & 18 \\
\hline
\end{tabular}

a The plasmid-dependent $\mathrm{Lac}^{+}$phenotype was determined as follows. Crude extracts containing hybrid plasmids were prepared from the transformants and strain CA7902 was transformed with these extracts. The plasmiddependent $\mathrm{Lac}^{+}$phenotype was expressed as the ratio of [number of $\mathrm{Lac}^{+}$phenotype]/[number of ampicillinresistances].

${ }^{b}$ Growth rates were determined on Davis-Mingioli minimal medium containing $10 \mu \mathrm{g} / \mathrm{ml}$ of ampicillin. In the case of strain CA7902R, this drug was omitted. Data represent the generation time in hours.

c Adenylate cyclase activity was assayed as described in MATERIALS AND METHODS. Activity was expressed as pmol of cAMP formed per $\mathrm{mg}$ of protein per $30 \mathrm{~min}$.

\section{Characterization of transformants}

To ascertain that the transformants obtained were carrying the cya gene, the following three ( $\mathrm{i} \sim$ iii) experiments were carried out using nine red colour-producing colonies (Table II; transformants $1 \sim 5$ and $11 \sim 14$ ) obtained by transformation with the chromosomal DNA digested for 30 min with HindIII.

(i) Transforming activity of hybrid plasmids

Cleared lysates were prepared from these transformants and used for the retransformation of CA7902. The cleared lysates from transformants 4,5 and $11 \sim 14$ could transform CA7902 to the $\mathrm{Lac}^{+}$phenotype. On the other hand, the cleared lysates from transformants 1, 2 and 3 failed in the complete conversion of CA7902 to $\mathrm{Lac}^{+}$phenotype (Table II).

(ii) Utilization of lactose and maltose

Utilization of maltose and lactose by these transformants was tested to check for contamination by lactose-constitutive strains, which can also produce a red colour on selection agar plates. Transformants 11, 12, 13 and 14 could grow on maltose as well as lactose and they showed the same growth rates as that of the CA7902R $\left(c y a^{+}\right)$strain. Transformants 1, 2, 3 and 4 also could grow on lactose, but their growth rates were much lower than those of CA7902R and/or transformants $11,12,13$ and 14. Transformant 5 also could grow on lactose and showed the same growth rate as that of CA7902R. But this strain could not utilize maltose.

(iii) Adenylate cyclase activity

Adenylate cyclase activities of red colourproducing colonies were determined. About 20 - to 30 -fold increases in adenylate cyclase activities were found in transformants 11,12 , 13 and 14 in comparison with that of CA7902. On the other hand, the activities of transformants 1, 2, 3, 4 and 5 remained at the same level as that of CA7902 or CA7902/pBR322.

Thus, four transformants (Transformants $11,12,13$ and 14) showed the same phenotype in utilization of lactose and maltose and in adenylate cyclase activity. The hybrid plasmids haboured in these four transformants were also the same in size, though the data are not shown here. So, one (Transformant 11) of the 
Table III. Size of Fragments Generated By Digestion With Various RESTRICTION ENDONUCLEASES

The conditions employed for the digestion were the same as those described by Murata et al. ${ }^{14)}$ BamHIHindIII and HindIII-Pst I double digestions were carried out under the conditions for HindIII. BamHI-EcoRI double digestion was carried out under the conditions for EcoRI.

\begin{tabular}{|c|c|c|}
\hline $\begin{array}{c}\text { Restriction } \\
\text { endonucleases }\end{array}$ & $\begin{array}{c}\text { Size of fragments } \\
(\mathrm{Md})\end{array}$ & $\begin{array}{c}\text { Total } \\
\text { size } \\
(\mathrm{Md})\end{array}$ \\
\hline HindIII & 3.252 .73 & 5.98 \\
\hline EcoRI & $4.91 \quad 1.31$ & 6.22 \\
\hline BamHI & $\begin{array}{lll}3.71 & 1.50 & 0.47\end{array}$ & 5.68 \\
\hline Pst I & $5.07 \quad 0.61$ & 5.68 \\
\hline BamHI-HindIII & $\begin{array}{lllll}2.23 & 1.50 & 1.30 & 0.47 & 0.42\end{array}$ & 5.92 \\
\hline HindIII-Pst I & $\begin{array}{lll}2.93 & 2.15 & 0.57\end{array}$ & 5.65 \\
\hline BamHI-Eco RI & $\begin{array}{llll}2.47 & 1.56 & 1.33 & 0.49\end{array}$ & 5.85 \\
\hline
\end{tabular}

four transformants was selected and used for further characterization of the hybrid plasmid and the extra- and intra-cellular levels of cAMP.

\section{Isolation and characterization of hybrid plasmid $p C A K-11$}

To characterize hybrid plasmids haboured in transformants, the hybrid plasmid, designated as pCAK-11, was extracted from Transformant 11 (Table II) and purified by $\mathrm{CsCl}$-ethidium bromide density gradient centrifugation. The results of restriction analysis of plasmid pCAK-11 are summarized in Table III.

From the results of restriction analysis, the size of this plasmid was determined to be 6.0 $\mathrm{Md}$, indicating that the $3.25 \mathrm{Md}$ (approximately 5 kilo base pairs) segment of chromosomal DNA was inserted into the HindIII site of pBR322. The size of this plasmid was calculated to be about $6.0 \mathrm{Md}$ from an electron micrograph (Fig. 1). The DNA fragment cloned onto pBR322 had a single susceptible site for Pst I and EcoRI and two for BamHI, but it contained no HindIII sites. Based on these results, the circular restriction map of hybrid plasmid pCAK-11 was determined as shown in Figure 2. Aiba independently cloned the $c y a$

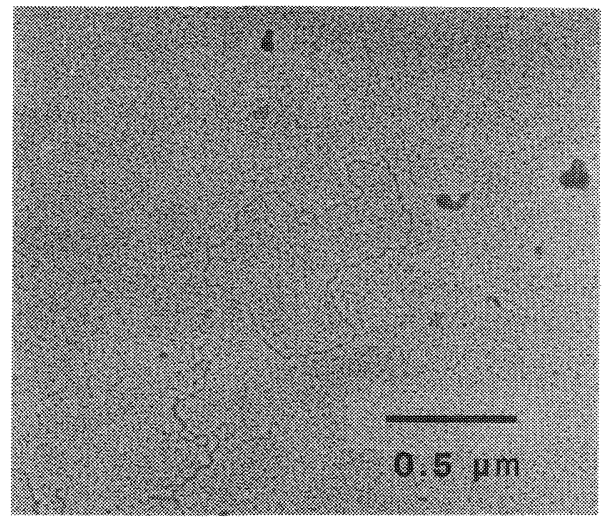

FIG. 1. Electron Micrograph of Hybrid Plasmid pCAK11.

The procedure for electron microscopy was the same as that described by Kleinschmit et al. ${ }^{20)}$ The photograph of plasmid DNA was taken at $\times 20,000$ magnitude. Contour length measurements were made on at least 9 molecules and the molecular weight was calculated taking pBR322 as an internal molecular weight standard.

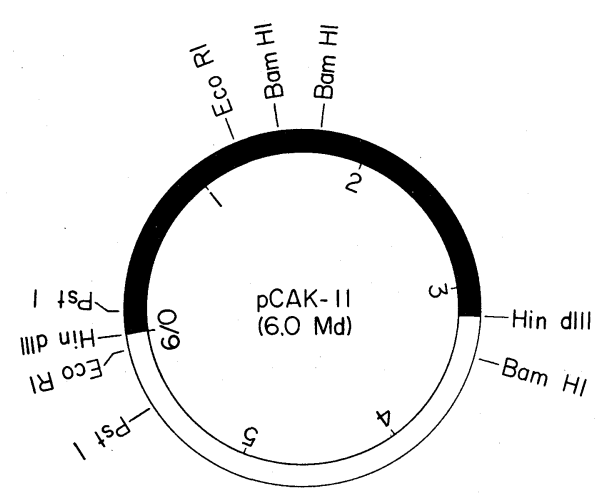

FIG. 2. Circular Restriction Map of Hybrid Plasmid pCAK-11.

The restriction sites are drawn relative to their scale on a circular map. The numbers in the circle represent megadaltons (Md). , chromosomal DNA of CA7902R; $\square$, vector plasmid pBR322.

gene of $E$. coli onto pBR322 and designated this hybrid plasmid as pCA1. pCA1 seemed to be the same as pCAK-11 in both molecular size and restriction pattern. The details of hybrid plasmid pCA1 will be described elsewhere.

Adenylate cyclase activity and CAMP contents of transformants

E. coli CA7902 $\left(c y a^{-}, c{ }^{+}, c p d^{+}\right)$, pp6 
Table IV. EfFect of pCAK-11 on Adenylate Cyclase Activity and cAMP Contents

\begin{tabular}{|c|c|c|c|c|}
\hline \multirow[b]{2}{*}{ Strain } & \multirow{2}{*}{$\begin{array}{l}\text { Relevant } \\
\text { genotype }^{a}\end{array}$} & \multirow{2}{*}{$\begin{array}{c}\text { Adenylate cyclase } \\
\text { activity }^{b} \\
\left.\text { (pmol } / 30 \mathrm{~min} / \mathrm{mg}^{-} \text {-protein }\right)\end{array}$} & \multicolumn{2}{|c|}{ cAMP content in ${ }^{b}$} \\
\hline & & & $\begin{array}{c}\text { Broth } \\
(\mathrm{nmol} / \mathrm{ml})\end{array}$ & $\begin{array}{c}\text { Cells } \\
\text { (nmol/g-wet } \\
\text { wt. cells) }\end{array}$ \\
\hline CA7902 & $c y a^{-}, c r p^{+}, c p d^{+c}$ & $2.8(1.0)$ & $\operatorname{trace}(-)$ & $0.17(1.0)$ \\
\hline CA7902/pCAK-11 & & $27 \quad(9.6)$ & $0.1(-)$ & $0.24(1.4)$ \\
\hline CA7902R & $c y a^{+}, c r p^{+}, c p d^{+}$ & $28 \quad(1.0)$ & $0.2(1.0)$ & $0.40(1.0)$ \\
\hline CA7902R/pCAK-11 & & $175 \quad(6.3)$ & $3.2(16)$ & $2.40(6.0)$ \\
\hline pp6 & $c y a^{+}, c r p^{+}, c p d^{+}$ & $141 \quad(1.0)$ & $0.3(1.0)$ & $4.40(1.0)$ \\
\hline pp6/pCAK-11 & & $269 \quad(1.9)$ & $0.8(2.7)$ & $6.40(1.6)$ \\
\hline pp47 & $c y a^{+}, c r p p^{-}, c p d^{+}$ & $239 \quad(1.0)$ & $50 \quad(1.0)$ & $14.0 \quad(1.0)$ \\
\hline pp 47/pCAK-11 & & $314 \quad(1.3)$ & $80 \quad(1.6)$ & $17.3(1.2)$ \\
\hline Crooke's & $c y a^{+}, c r p^{+}, c p d^{-}$ & $29 \quad(1.0)$ & $5.2(1.0)$ & $6.80(1.0)$ \\
\hline Crooke's/pCAK-11 & & $140 \quad(4.8)$ & $8.2(1.6)$ & $6.80(1.0)$ \\
\hline
\end{tabular}

a Genotypes are listed in relation to cAMP.

$b$ Adenylate cyclase activity and cAMP contents of broth and of cells were assayed as described in MATERIALS AND METHODS. In parenthesis is shown the relative activity or content.

c Gene for cAMP phosphodiesterase.

$\left(c y a^{+}, c r p{ }^{+}, c p d^{+}\right), \operatorname{pp} 47\left(c y a^{+}, c r p^{-}, c p d^{+}\right)$ and Crooke's $\left(c y a^{+}, c r p^{+}, c p d^{-}\right)$were transformed with hybrid plasmid pCAK-11 and adenylate cyclase activity and intra- and extracellular levels of cAMP in the transformants were determined. These results are summarized in Table IV.

Adenylate cyclase activity of CA7902/ pCAK-11 was about 10 -fold higher than that of CA7902 as a control. But, a marked increase in adenylate cyclase activity was not observed in the case of strains such as pp6 and pp47.

Intra- and extra-cellular contents of cAMP also increased on introduction of hybrid plasmid pCAK-11 into various recipient strains of $E$. coli. Especially marked extracellular accumulation of cAMP was observed for strain pp47 having a deficiency in cAMP-receptor protein (CRP). A strain deficient in cAMPphosphodiesterase (CPD) activity (Crooke's) was also found to accumulate a large amount of cAMP in both the cells and broth. The introduction of hybrid plasmid pCAK-11 into Crooke's strain also resulted in an increase in adenylate cyclase activity.

\section{DISCUSSION}

The chromosomal segment carrying the cya gene of E. coli CA7902R was cloned onto pBR322. The following three facts indicated that this segment contained the cya gene. (i) pCAK-11 could transform CA7902 (cya $\left.{ }^{-}\right)$to $\mathrm{Lac}^{+}$. (ii) Cells habouring this hybrid plasmid could utilize both lactose and maltose. (iii) pCAK-11 gave rise to adenylate cyclase activity. However, the method we used for the selection of transformants was not specific for the hybrid plasmid carrying the cya gene. Spontaneous revertants of CA7902 habouring a hybrid plasmid and several lactoseconstitutive strains also show a red colour on selection plates. So, the properties of redcolour producing colonies that appeared on the selection plates were analyzed (Table II). As a result, four (Transformants 11, 12, 13 and 14 in Table II) were found to be intrinsic transformants carrying the hybrid plasmid with the cya gene. Besides these four strains, various transformants were obtained (Table II). But, they showed little adenylate cyclase activity, although they had interesting characters as to sugar utilization.

The cloning of the cya gene was also re- 
ported by Clark et al., ${ }^{21)}$ Roy et al. ${ }^{22)}$ and Wang et al., ${ }^{23)}$ respectively. Clark et al. obtained the cya gene of E. coli, but they did not report on it in detail. Roy et al. presented a restriction map of the cya region on plasmid pLC 41.04. Wang et al. isolated the cya gene from Salmonella by the transformation of $E$. coli using $\lambda \mathrm{gt} 4$ phage as a cloning vector. They have concluded that 2.6 k.b.p. is essential for coding the cya gene of this organism. The size of the cloned segment obtained in our experiment was 5.0 k.b.p. This size seemed to be sufficient to cover the adenylate cyclase.

The increase in adenylate cyclase activity in transformants was host strain-dependent (Table IV). Five- to ten-fold increases in this enzyme activity were observed, when the strains (CA7902, CA7902R and Crooke's) having low adenylate cyclase activity were used as recipients. On the other hand, such an increase in activity was not observed, when the recipient strains (pp6 and pp47) had relatively high adenylate cyclase activity. The reason for this strain dependent activity of adenylate cyclase is now obscure. The expression of the cya gene on a hybrid plasmid may be controlled by various factors determining the contents of intra- and extra-cellular cAMP.

Increased levels of intra- and extra-cellular contents of cAMP were found in cells dosed with the cya gene. An especially marked increase in the extracellular content of cAMP was found in a strain deficient in cAMPreceptor protein (CRP). Although the relationship between the $\mathrm{crp}^{+}$phenotype and control of the cAMP level is now obscure, the same results were also presented by many investigators. ${ }^{7,24,25)}$ A cAMP-phosphodiesterase (CPD) activity deficient strain (Crooke's) also showed high levels of extra- and intra-cellular accumulation of cAMP. Therefore, it was suggested that $c r p^{-}$and $c p d^{-}$may be necessary for the accumulation of a large amount of cAMP.

From this standpoint, we are studying the construction of a mutant strain having a deficiency in both CRP and CPD for the production of a large amount of cAMP. We are also carrying out detailed analysis of the effect of the $\mathrm{crp}^{-}$phenotype on the accumulation of cAMP.

Acknowledgments. We thank Dr. M. Sakaguchi, the Research Institute for Food Science, Kyoto University, for his kind and critical suggestions for this work. We also want to express our sincere thanks to $T$. Higasa, the Research Institute for Food Science, Kyoto University, for taking the electron microscope pictures. Thanks are also due to Dr. M. Yamazaki, Faculty of Agriculture, Tokyo University, for generous sharing of strains.

\section{REFERENCES}

1) J. L. Botsfold, Microbiol. Rev., 45, 620 (1981).

2) H. V. Rickenberg, Ann. Rev. Microbiol., 28, 353 (1974).

3) E. M. Ross and A. G. Gilman, Ann. Rev. Biochem., 49, 533 (1980).

4) I. Pastan and S. Adhya, Bacteriol. Rev., 40, 527 (1976).

5) H. Aiba, S. Adhya and B. de Crombrugghe, J. Biol. Chem., 256, 11905 (1981).

6) I. H. Mejerfeld, D. Miller, E. Spits and H. V. Rickenberg, Mol. Gen. Genet., 181, 470 (1981).

7) F. Wayne and O. M. Rosen, Proc. Natl. Acad. Sci. U.S.A., 71, 1436 (1974).

8) E. A. Adelberg, M. Mandel and G. C. C. Chen, Biochem. Biophys. Res. Commun., 18, 788 (1965).

9) K. Miura, Methods in Enzymology, 12, 543 (1967).

10) D. B. Clewell and R. R. Helinsky, Proc. Natl. Acad. Sci. U.S.A., 62, 1169 (1969).

11) A. Ullrich, J. Shine, J. Chirgwin, P. Pictet, E. Tischer, W. J. Rutter and H. M. Goodman, Science, 196, 1313 (1977)

12) T. Tanaka and B. Weisblum, J. Bacteriol., 121, 354 (1975).

13) S. R. Kushner, "Genetic Engineering," ed. by H. W. Boyer and S. Nicosia, Elsevier, North-Holland Biochemical Press, 1978, p. 17.

14) K. Murata and A. Kimura, Appl. Environ. Microbiol., 44, 1444 (1982).

15) R. B. Helling, H. M. Goodman and H. W. Boyer, $J$. Virol., 14, 1235 (1974).

16) M. Tao and A. Huberman, Arch. Biochem. Biophys., 141, 236 (1970).

17) B. D. Davis and E. S. Mingioli, J. Bacteriol., 60, 17 (1950).

18) O. H. Lowry, N. J. Rosebrough, A. L. Farr and R. J. Randall, J. Biol. Chem., 193, 265 (1951).

19) D. Schwartz and J. Beckwith, "The Lactose Operon," ed. by R. Beckwith and D. Zipser, Cold Spring Harbor Laboratory, Cold Spring Harbor, N. Y., 1970, p. 417.

20) A. K. Kleinschmit, D. Land, D. Jacherts and R. K. 
Zahn, Biochim. Biophys. Acta, 61, 857 (1962).

21) L. Clark and J. Carbon, Cell, 9, 91 (1976).

22) A. Roy and A. Danchin, Biochimie, 63, 719 (1981).

23) J. Y. J. Wang, D. O. Clegg and D. E. Koshland, Jr., Proc. Natl. Acad. Sci. U.S.A., 78, 4684 (1981).
24) A. D. E. Fraser and H. Yamazaki, Can. J. Microbiol., 24, 1423 (1978).

25) K. Potter, G. C. Larsson and H. Yamazaki, Biochem. Biophys. Res. Commun., 57, 379 (1974). 